\title{
POLA PENGEMBANGAN RUMAH DI KAMPUNG KOTA DAN FAKTOR-FAKTOR YANG MEMPENGARUHINYA
}

\author{
Nina Nurdiani \\ Jurusan Arsitektur, Fakultas Sains dan Teknologi, Universitas Bina Nusantara \\ Jln K.H. Syahdan No. 9, Kemanggisan, Palmerah, Jakarta Barat \\ nnurdiani@binus.edu / nina.nurdiani@yahoo.co.id
}

\begin{abstract}
The housing development is done by city kampong society self-supportingly at its growth become very difficult to be controlled. To make sustainable environment in city kampong hence require to be done a research concerning Pattern of Housing Development in City Kampong and the Factors Its Influence. This research used Descriptive-Analytical research method and take case study in Bidara Cina Kampong, Bidara Cina sub-district, Jatinegara district, East Jakarta. Result of this research indicates that the increasing of prosperity of society in city kampong which generally is middle income society to low income tend to be accompanied by degradation of environmental quality of its settlement. This condition happened because ably limited economics and very the limited wide of land of private. The kampong society tending to develop bedroom and living room as multi function room, and at the process development of house heedless of neighbors environment. Dominant factors influence pattern of housing development in city kampong alternately is social-culture factors, condition of physical land and house factors, economics factors, requirement of human being factors, and non-physical factors (legality of land and house).
\end{abstract}

Keywords: city kampong's house, pattern of housing development

\begin{abstract}
ABSTRAK
Pembangunan atau pengembangan rumah yang dilakukan masyarakat kampung kota secara swadaya pada perkembangannya menjadi sangat sulit untuk dikendalikan dengan baik. Untuk dapat mengendalikan pembangunan rumah secara spontan oleh masyarakat maka perlu dilakukan penelitian mengenai Pola Pengembangan Rumah di Kampung Kota dan Faktor - faktor yang Mempengaruhinya. Penelitian ini menggunakan metode penelitian Deskriptif - Analitis dan mengambil studi kasus di Kampung Bidara Cina, kelurahan Bidara Cina, kecamatan Jatinegara, Jakarta Timur. Hasil penelitian menunjukkan bahwa peningkatan kesejahteraan masyarakat di kampung kota yang umumnya adalah masyarakat golongan menengah ke bawah, cenderung disertai penurunan kualitas lingkungan permukimannya. Kondisi demikian terjadi karena dengan kemampuan ekonomi terbatas dan sangat terbatasnya luas lahan privat. Masyarakat cenderung mengembangkan ruang tidur dan ruang keluarga (ruang multi fungsi), pada proses pembangunan rumah tidak memperhatikan lingkungan tetangga/sekitarnya. Faktor-faktor yang dominan mempengaruhi pola pengembangan rumah di kampung kota secara berurutan adalah (1) Faktor sosial budaya, (2) Faktor kondisi fisik lahan dan rumah, (3) Faktor ekonomi, (4) Faktor kebutuhan manusia, (5) Faktor non fisik rumah.
\end{abstract}

Kata kunci: pola pengembangan rumah, rumah kampung kota 


\section{PENDAHULUAN}

Pertumbuhan penduduk yang terus meningkat di kota Jakarta terutama akibat meningkatnya arus urbanisasi penduduk, mengakibatkan meningkatnya penggunaan lahan di Jakarta dari tahun ke tahun. Data Biro Pusat Statistik (BPS) Jakarta menunjukkan bahwa dalam kurun waktu lima tahun terakhir, tidak kurang dari 178 Ha lahan terbuka di Jakarta beralih fungsi menjadi lahan tertutup atau terbangun (Anung, 2002). Perluasan penggunaan lahan terjadi ke segala arah yaitu terjadi ke arah timur, barat dan selatan kota Jakarta, dans sedikit ke arah utara Jakarta melalui reklamasi. Dari prosentase luas penggunaan lahan di Jakarta, kebutuhan luas lahan untuk perumahan di Jakarta menempati jumlah terbesar. Menurut Tobing (2002) bahwa berdasarkan data Biro Pusat Statistik (BPS) Jakarta, prosentase penggunaan lahan perumahan menduduki prosentase tertinggi yaitu $36.65 \%$.

Dari luas lahan perumahan yang terbangun di wilayah kota Jakarta, sebesar 27,5\% merupakan perumahan yang terencana dan $72,5 \%$ merupakan perumahan yang tidak terencana. Kondisi ini terjadi karena pemenuhan kebutuhan akan perumahan tersebut sangat terkait dengan pengadaan perumahan yang dilakukan oleh pemerintah, swasta dan masyarakat. Selain itu, mayoritas para pendatang kota Jakarta adalah masyarakat berpenghasilan rendah yang belum mampu membeli rumah sehingga mereka memadati perkampungan yang ada di perkotaan.

Kebutuhan akan rumah dan keterbatasan pengadaan rumah oleh sektor-sektor formal mendorong masyarakat, terutama masyarakat di kampung kota, untuk cenderung melakukan pembangunan rumah sendiri baik secara individu maupun secara swadaya dengan masyarakat setempat, sesuai kemampuan masing-masing. Pelaksanaan pembangunan dan pengembangan rumah oleh masyarakat tersebut mengakibatkan perkembangan lingkungan permukiman menjadi tidak terkendali dan tidak terawasi dengan baik, karena keterbatasan pengetahuan masyarakat tentang aturan pengendalian pembangunan dan pengembangan rumah di lingkungan perkotaan. Langkanya lahan di perkotaan sebagai sumber daya perumahan dan luas lahan yang sangat terbatas juga mendorong masyarakat cenderung memaksimalkan penggunaan lahan yang mereka miliki untuk pembangunan dan pengembangan rumah.

Rumah merupakan salah satu kebutuhan pokok manusia sebagai tempat berlindung dan berteduh yang akan terus bertambah dan berkembang seiring dengan perkembangan dan peningkatan kebutuhan manusia akan rumah sesuai kondisi sosial-ekonomi masing-masing. Faktor-faktor yang mempengaruhi masing-masing individu dalam kegiatannya tersebut adalah faktor intern dan faktor ekstern (Sai S, 1993). Setiap individu pemilik rumah terlebih dahulu akan memenuhi kebutuhan dasar akan rumah yaitu sebagai tempat berlindung yang aman dan membangun ruang-ruang utama yang diperlukan oleh mereka. Setelah kebutuhan pokok terpenuhi mereka mulai melakukan perubahan dan pengembangan terhadap huniannya untuk memenuhi kebutuhan penunjang akan rumah, seperti memperluas ruangan, menambah ruangan, meningkatkan kualitas fisik rumah, memperindah bentuk rumah, dan lain-lain, sesuai kondisi sosial-ekonominya. Tentunya upaya-upaya yang dilakukan masyarakat kampung kota dalam memanfaatkan lahan yang ada di lingkungan mereka, untuk membangun dan mengembangkan rumah dalam rangka memenuhi kebutuhan dan keinginan mereka, dilatarbelakangi oleh berbagai faktor yang perlu dipertimbangkan juga.

Agar dapat dilakukan pengendalian terhadap pembangunan dan pengembangan rumah yang lebih efektif di kampung kota, maka perlu diketahui pertama bagaimana pola pengembangan rumah yang dilakukan masyarakat kampung kota dalam membangun dan mengembangkan rumahnya, dan kedua faktor-faktor apa yang mempengaruhi pola pengembangan rumah di kampung kota.

Tujuan penelitian yang dilakukan adalah untuk mengetahui dan mendapatkan gambaran mengenai pola pengembangan rumah oleh masyarakat kampung kota, untuk mengetahui dan mendapatkan penjelasan mengenai faktor-faktor yang mempengaruhi pola pengembangan rumah di 
kampung kota. Manfaat penelitian adalah untuk (1) memberi pengetahuan mengenai pola pengembangan rumah yang terjadi di kampung kota, serta faktor-faktor yang mempengaruhi pola pengembangan rumah di lingkungan kampung kota; (2) merekomendasikan penyelesaian teknis dan tata ruang dalam perkembangan permukiman; (3) memberi masukan bagi pengembangan strategi dan kebijakan pengendalian pembangunan perumahan yang lebih efisien dan efektif di kampung kota, demi tercapainya pelestarian lingkungan kampung kota yang berwawasan lingkungan.

Penelitian ini mengambil studi kasus salah satu area kampung kota tua di Jakarta yang padat yang telah melalui proses pengembangan dan perluasan lahan permukiman. Kampung kota terpilih yaitu wilayah kelurahan Bidara Cina, kecamatan Jatinegara, Jakarta Timur. Lokasi kampung Bidara Cina memiliki letak yang cukup strategis karena dekat dengan pusat-pusat kegiatan kota seperti pasar Jatinegara, pusat komersial, perkantoran, dan lain-lain. Hal ini juga menyebabkan kampung Bidara Cina cenderung semakin padat baik oleh masyarakat pribumi sendiri (Betawi-Arab) maupun kaum pendatang. Kondisi seperti ini memungkinkan proses pemadatan lingkungan, proses pembangunan dan pengembangan rumah secara spontan oleh masyarakat yang dapat terus menerus terjadi. Untuk mengetahui pola pengembangan rumah yang terjadi di kampung kota, maka lokasi penelitian terpilih adalah area di wilayah kelurahan Bidara Cina yang memiliki ciri-ciri lingkungan kampung yaitu yang area permukimannya tidak terencana atau tidak teratur sebagai hasil perkembangan yang tumbuh secara spontan.

\section{METODE}

Untuk menggambarkan karakteristik pola pengembangan rumah yang dilakukan oleh masyarakat kampung kota, serta mengetahui dan menganalisis faktor-faktor yang mempengaruhi pola pengembangan rumah tersebut, maka jenis penelitian yang digunakan adalah penelitian Deskriptif Analitis. Untuk mendapatkan data-data yang dibutuhkan, maka dilakukan cara pendekatan dengan metode survey dan pengamatan. Pada penelitian ini metode survey dilakukan untuk mendapatkan gambaran karakteristik pola pengembangan rumah oleh masyarakat di kampung kota dan faktor-faktor yang mempengaruhinya. Sedangkan metode pengamatan yaitu pengumpulan data langsung di lapangan dilakukan untuk dapat mengidentifikasi kondisi fisik dan non fisik di lingkungan kampung kota sebagai hasil dari pembangunan dan pengembangan rumah oleh masyarakat setempat.

Variabel-variabel yang digunakan dalam penelitian yang terkait dengan tujuan penelitian atau untuk menjawab pertanyaan penelitian adalah (1) pola pembangunan dan pengembangan rumah oleh masyarakat kampung kota pada lahan privat. Variabel ini digunakan dan dianalisis untuk mengetahui pola pengembangan rumah yang terjadi di kampung kota. (2) Faktor intern, yaitu kebutuhan-kebutuhan setiap individu masyarakat kampung kota terhadap rumahnya. Variabel ini digunakan dan dianalisis untuk mengetahui faktor-faktor dari dalam diri individu yang mempengaruhi pola pengembangan rumah oleh masyarakat kampung kota. (3) Faktor ekstern, yaitu faktor sosial budaya, tingkat kesadaran lingkungan, faktor ekonomi, dan faktor kondisi fisik rumah. Variabel ini digunakan dan dianalisis untuk mengetahui faktor-faktor yang berasal dari luar (faktor eksternal) diri setiap individu yang mempengaruhi pola pengembangan rumah oleh masyarakat kampung kota.

Definisi operasional variabel dari variabel-variabel penelitian yang telah diuraikan di atas beserta skala pengukurannya adalah (1) Pola pembangunan dan pengembangan rumah oleh masyarakat kampung kota pada lahan privat, yaitu luas lahan dan bangunan, jenis dan jumlah ruang yang tersedia, jenis dan luas serta jumlah ruang yang dikembangkan, jenis pengembangan rumah secara horisontal yang dilakukan masyarakat, arah pengembangan secara horisontal pada lahan privat, material bangunan yang digunakan untuk menutup permukaan tanah pada lahan privat. Skala pengukuran yang digunakan adalah skala nominal dan skala ordinal. (2) Faktor Intern, yaitu 
kebutuhan-kebutuhan setiap individu masyarakat kampung kota terhadap rumahnya antara lain kebutuhan fisiologis (dasar), rasa aman dan privacy, sosial, harga diri dan aktualisasi diri. Skala pengukuran yang digunakan adalah skala ordinal. (3) Faktor Ekstern, yaitu faktor sosial (tingkat pendidikan dan tingkat kesadaran lingkungan, latar belakang budaya/asal daerah, jumlah anggota keluarga), faktor ekonomi (jenis pekerjaan, tingkat pendapatan dan besar biaya yang disediakan untuk keperluan rumah), dan faktor kondisi fisik rumah (luas lahan dan bangunan). Skala pengukuran yang digunakan adalah skala nominal dan skala ordinal.

\section{Metode Sampling, Teknik Pengumpulan Data, dan Metoda Analisis Data}

Populasi penelitian adalah semua penduduk kampung kota dan rumahnya yang berlokasi di Kelurahan Bidara Cina, Kecamatan Jatinegara, Jakarta Timur, yaitu berjumlah sekitar 3213 rumah yang kondisi fisik lingkungannya mencerminkan ciri-ciri permukiman kampung kota. Karena jumlah unit yang distudi relatif besar, maka digunakan sampel yang dipilih dan dianggap dapat mewakili ciriciri populasi (representatif). Teknik penarikan sampel dilakukan secara purposive sampling. Satuan kajian analisis penelitian ini adalah individu anggota masyarakat kampung kota setempat yang memiliki sekaligus menghuni rumah, dan unit-unit lahan privat beserta rumahnya. Dari penjelasan di atas, maka lokasi penelitian dan unit analisis terpilih yang ditentukan secara purposive berdasarkan tujuan penelitian dan dianggap dapat mewakili populasi dan ciri-ciri permukiman kampung kota adalah wilayah Rukun Warga (RW) 007 dan sebagian kecil RW 006, Kelurahan Bidara Cina, Kecamatan Jatinegara, Jakarta Timur (lihat Gambar 1). Kemudian dari lokasi penelitian tersebut terpilih 3 (tiga) area kepadatan sebagai sampel lokasi, yaitu area kepadatan rendah, area kepadatan sedang dan area kepadatan tinggi. Tingkat kepadatan ditentukan berdasarkan perhitungan luas lahan yang terbangun di lingkungan kampung kota. Sehingga pada lokasi penelitian yaitu RW 007 dan sebagian kecil RW 006, terpilih secara purposive 6 (enam) Rukun Tetangga (RT). Setiap 2 (dua) RT dianggap dapat mewakili populasi dan satu area kepadatan. Dari setiap RT terpilih, jumlah sampel ditentukan sampai mencapai kejenuhan informasi, dan minimal jumlah sampel tersebut 30 sampel untuk setiap area kepadatan agar dapat diuji secara statistik.

Untuk mengumpulkan Data-data Primer pada penelitian ini, maka digunakan (1) Teknik Kuesioner, yaitu mengajukan pertanyaan tertulis dengan sistem tertutup dan setengah terbuka untuk mendapatkan informasi dan gambaran dari responden tentang kondisi sosial budaya dan ekonomi mereka, serta pendapat mereka tentang rumahnya dan kondisi lingkungannya. (2) Teknik Wawancara, yaitu mengajukan pertanyaan secara lisan yang dilakukan pewawancara kepada tokoh masyarakat setempat, untuk mendapatkan gambaran mengenai kondisi masyarakat secara umum, dan perkembangan kampung di lokasi penelitian, dan lain-lain. (3) Teknik observasi, yaitu pengamatan langsung di lapangan, dengan menggunakan seluruh panca indera, dengan cara menghitung, mengukur dan mencatat kondisi fisik rumah dan lingkungannya.

Untuk mengumpulkan data-data sekunder pada penelitian ini, maka dilakukan pengumpulan data mengenai aturan pembangunan/pengembangan rumah, kebijakan perumahan/permukiman, serta data statistik kependudukan khususnya pada studi kasus penelitian. Data-data sekunder tersebut dapat berupa tulisan, literatur, peta, gambar dari berbagai sumber seperti buku, jurnal, tesis-tesis penelitian, artikel-artikel di media tertulis (koran, majalah, dan lain-lain), teori-teori dan konsep yang sangat relevan dengan masalah penelitian yang akan dipecahkan. Selain itu pengumpulan data sekunder dilakukan juga dengan menggunakan kamera foto, dan membuat gambar sketsa rumah beserta tata ruang luarnya. Pengambilan gambar/foto kondisi fisik lingkungan permukiman tersebut dilakukan untuk mendapatkan data tentang pola pembangunan dan pengembangan rumah yang dilakukan masyarakat di kampung kota. 


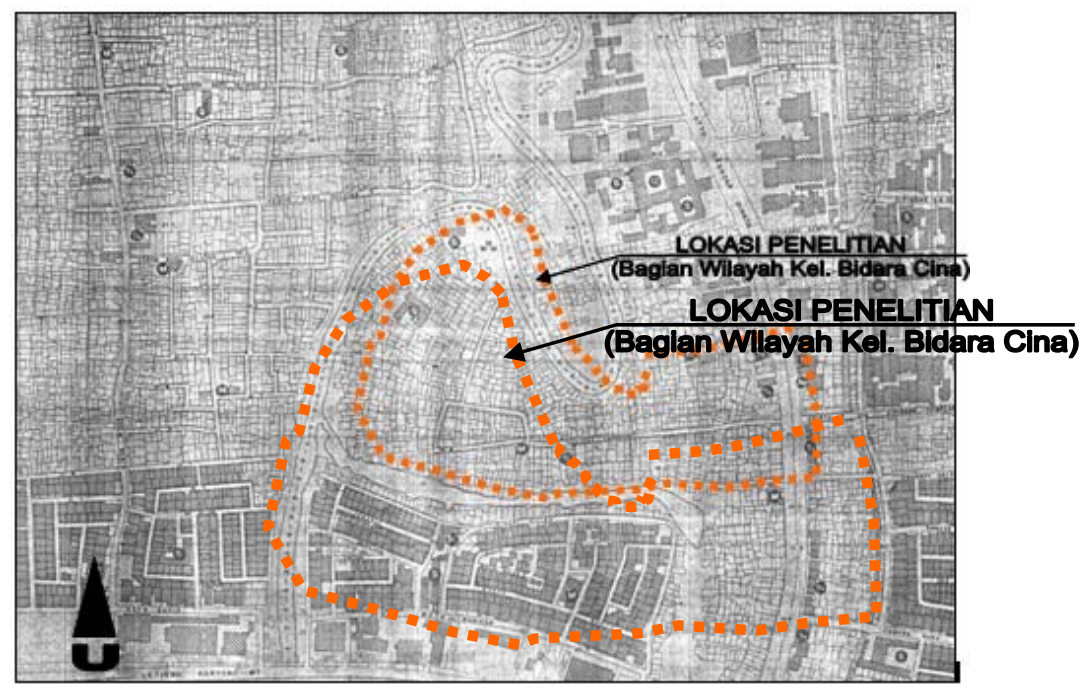

Gambar 1 Peta lokasi penelitian pola pengembangan rumah di kampung kota.

Analisis dilakukan dengan cara deskriptif, yaitu memberikan gambaran dan penjelasan dari studi kasus penelitian melalui persentase, rata-rata, dan lain-lain, untuk menjawab masalah pola pengembangan rumah di kampung kota. Sedangkan analisis statistik non-parametrik dengan uji korelasi digunakan untuk dapat menjawab masalah faktor-faktor yang melatarbelakangi kegiatan pembangunan dan pengembangan rumah oleh masyarakat kampung kota. Teknik pengujian dibantu dengan perhitungan komputer program SPSS.11, dengan tingkat signifikansi yang digunakan dalam penelitian ini adalah $\alpha=0.05$.

\section{HASIL DAN PEMBAHASAN}

Pada dasarnya kegiatan pembangunan dan perluasan rumah yang dilakukan oleh masyarakat kampung kota secara swadaya untuk memenuhi kebutuhannya akan rumah, akan menghasilkan suatu pola pengembangan rumah. Selama ini kegiatan pembangunan dan perluasan rumah oleh masyarakat kampung kota pada lahan privat yang mereka miliki dilakukan dengan cara memaksimalkan pemanfaatan lahan yang ada, untuk memenuhi kebutuhannya akan rumah. Apabila kegiatan tersebut dilakukan secara berlebihan tanpa pengendalian, maka kegiatan tersebut dapat berdampak negatif pada lingkungan yaitu semakin berkurangnya daerah atau lahan resapan air di lingkungan kampung kota. Pola pengembangan rumah tersebut meliputi banyaknya kegiatan dan tahapan pengembangan rumah yang dilakukan masyarakat setempat, serta arah pengembangan dan ruang-ruang yang dikembangkan. Dengan mengetahui hal-hal di atas, maka diharapkan pengendalian kegiatan pengembangan rumah di kampung kota dapat dilaksanakan dengan baik melalui pendekatan yang sesuai dengan kondisi lingkungan setempat.

\section{Pola Pengembangan Rumah di Kampung Kota}

Untuk memenuhi kebutuhannya akan rumah, masyarakat umumnya melakukan kegiatan membangun dan memperluas rumahnya. Sedangkan tahapan pengembangan dilakukan oleh masyarakat kampung kota yang melakukan perluasan rumahnya. Dari hasil survey diketahui bahwa masyarakat kampung Bidara Cina cenderung tidak memperluas rumahnya yang asli. Mereka umumnya melakukan pembangunan rumah saja (lihat Gambar $2 a$ dan $2 b$ ). Kondisi seperti ini berlaku di tiga area kepadatan yang berbeda. Sehingga dari seluruh responden, yang menyatakan tidak memperluas rumahnya sebesar $58.89 \%$ dan yang menyatakan memperluas rumahnya sebesar $41.11 \%$. 

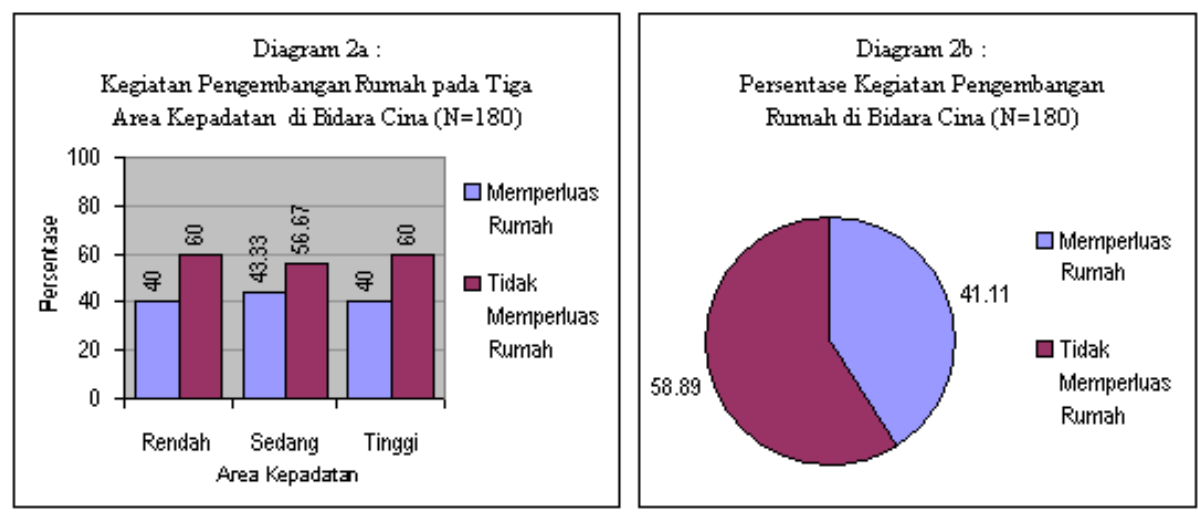

Gambar 2a Kegiatan Pengembangan Rumah pada Tiga Area Kepadatan di Bidara Cina; Gambar 2b Presentase Kegiatan Pengembangan Rumah di Bidara Cina

Kecenderungan masyarakat tidak memperluas rumahnya (58.89\%), karena umumnya kegiatan pembangunan rumah yang dilakukan mereka adalah untuk memenuhi kebutuhan dasar akan rumah, yang terkait dengan fungsi. Mereka lebih memprioritaskan pembangunan rumah awal dan melengkapinya dengan ruang-ruang pokok/utama yang menurut mereka sangat penting ada di dalam suatu rumah, meskipun dengan luas ruang di bawah standar karena luas lahan mereka terbatas. Kemampuan ekonomi mereka yang terbatas juga menyebabkan mereka tidak melakukan perluasan rumah, tetapi hanya melakukan perawatan dan perbaikan rumah bila ada material bangunan yang rusak atau harus diganti.
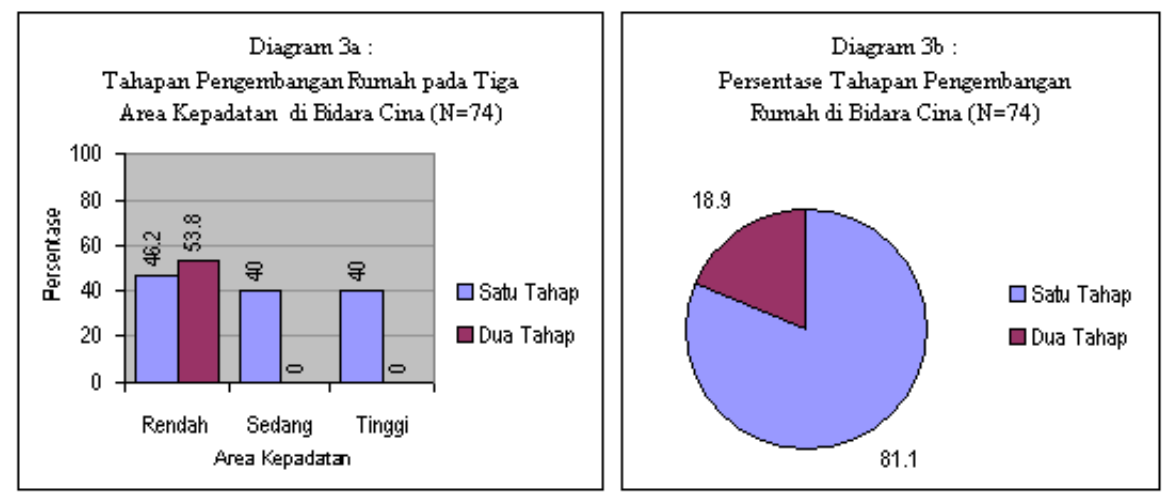

Gambar 3a Tahapan Pengembangan Rumah pada Tiga Area Kepadatan di Bidara Cina; Gambar 3b Presentase Tahapan Pengembangan Rumah di Bidara Cina

Di kampung Bidara Cina masyarakat melakukan perluasan rumah $(41.11 \%)$ melalui dua tahapan pengembangan. Selain untuk memenuhi kebutuhan ruang-ruang utama dalam rumah, kegiatan ini dilakukan untuk menambah jumlah ruang, memperluas ruang yang ada, atau memperindah rumah mereka. Hal ini dilakukan apabila tersedia biaya untuk rumah atau kondisi ekonomi keluarga meningkat. Dari seluruh responden yang memperluas rumah (41.11\%), masyarakat kampung kota cenderung memperluas rumah mereka dalam satu tahap. Dari hasil survey didapat bahwa $81.1 \%$ responden memperluas rumah dalam satu tahap dan $18.9 \%$ responden memperluas rumah dalam dua tahap. Perluasan rumah dalam satu tahap dilakukan oleh semua responden yang mengembangkan rumah di tiga area kepadatan berbeda. Sedangkan perluasan rumah dalam dua tahap umumnya dilakukan di area kepadatan rendah (lihat Gambar 3a dan 3b). Perluasan rumah dalam dua tahap lebih banyak terjadi di area kepadatan rendah (lihat Gambar 3a dan 3b), karena pada area tersebut masih terdapat lahan privat yang memungkinkan untuk dibangun, dan pada area ini kemampuan ekonomi masyarakatnya cenderung lebih tinggi dari dua area lainnya (lihat Gambar 4a dan 4b). Apabila masih ada lahan yang dapat dibangun, perluasan rumah tahap pertama dilakukan dengan memanfaatkan sisa 
lahan yang ada. Tetapi bila tidak ada lagi lahan yang dapat dibangun, masyarakat cenderung mengembangkan rumah mereka ke atas (bertingkat).
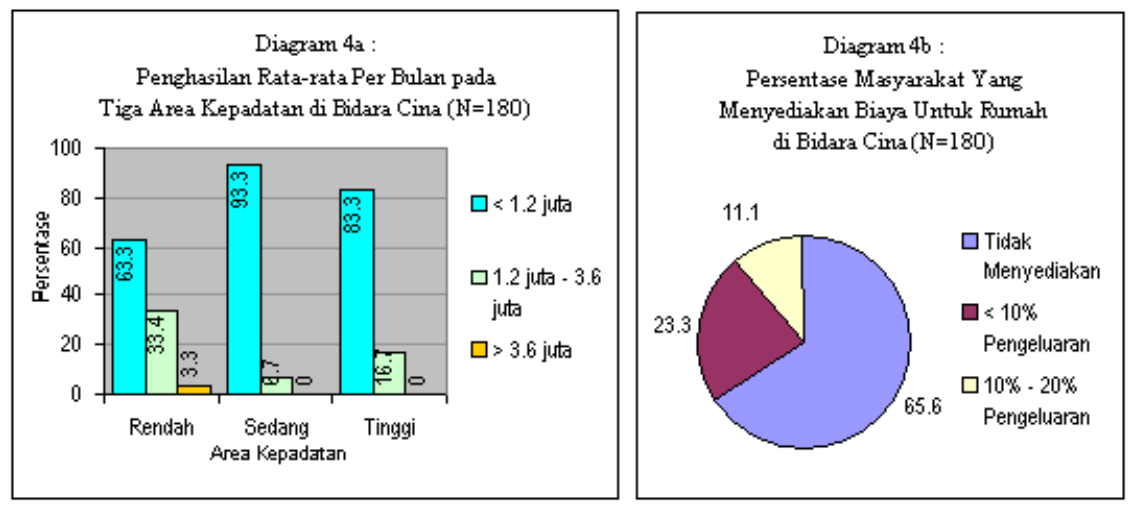

Gambar 4a Penghasilan Rata-Rata per Bulan pada Tiga Area Kepadatan di Bidara Cina; Gambar 4b Presentase Masyarakat yang Menyediakan Biaya untuk Rumah di Bidara Cina

Dari pembahasan di atas dapat disimpulkan bahwa masyarakat kampung kota cenderung tidak memperluas rumahnya karena kemampuan ekonomi yang terbatas. Meskipun mereka melakukan kegiatan pembangunan rumah untuk memenuhi kebutuhan dasar akan rumah, tetapi pemanfaatan lahan privat secara maksimal (arah horisontal) sudah mulai dilakukan pada tahap awal pembangunan rumah mereka, karena terbatasnya luas lahan yang dimiliki oleh masyarakat kampung kota. Tahapan pengembangan atau perluasan rumah dilakukan oleh masyarakat kampung kota, apabila kondisi ekonomi mereka meningkat. Pemanfaatan lahan secara maksimal arah horisontal yang umum dilakukan masyarakat kampung kota untuk pengembangan rumahnya, dapat berdampak pada berkurangnya lahan yang dapat meresapkan air di lingkungan kampung kota (lihat gambar 5).
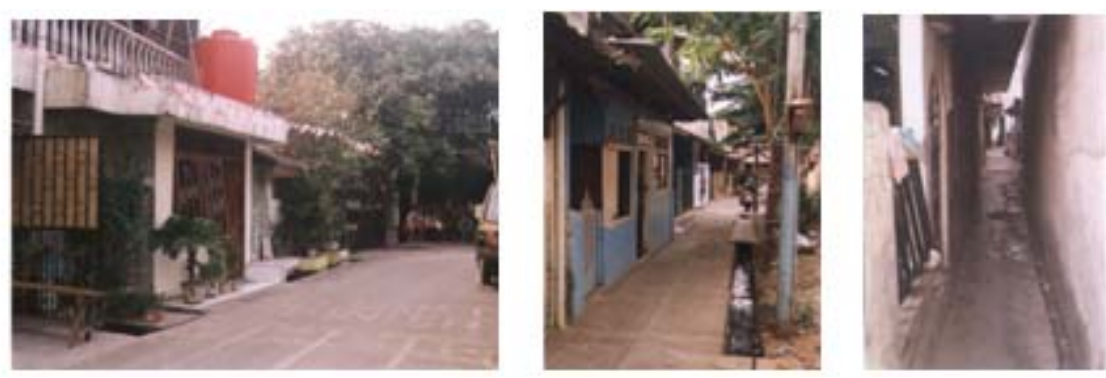

Gambar 5 Pengembangan rumah yang memaksimalkan lahan yang ada.

Dalam melakukan kegiatan perluasan rumah, masyarakat kampung kota cenderung lebih banyak melakukan pengembangan rumah secara horisontal dalam memanfaatkan lahan privat yang ada. Arah pengembangan horisontal yang umum dilakukan masyarakat pada tahapan pengembangan rumahnya adalah arah belakang. Hasil survei menunjukkan bahwa dari responden yang memperluas rumah $(41.11 \%)$, yang menyatakan mengembangkan secara horisontal $64.9 \%$ responden dan yang mengembangkan secara vertikal $35.1 \%$ responden. Dari responden yang memperluas rumah juga (41.11\%), yang menyatakan mengembangkan ke arah belakang $43.8 \%$ responden dan sisanya $56.2 \%$ responden mengembangkan rumah ke arah lain, yaitu secara berurutan adalah arah depan, samping kiri dan samping kanan (lihat diagram 5a, diagram 5b, dan gambar 3).

Pengembangan rumah secara horisontal cenderung dipilih masyarakat, karena biaya yang dikeluarkan tidak semahal pengembangan vertikal. Arah pengembangan rumah secara horisontal 
banyak dilakukan ke arah belakang karena pada awal pembangunan masyarakat cenderung menyisakan lahan di bagian belakang dan depan rumah untuk menjemur pakaian, memelihara binatang, dan lain-lain. Apabila perlu ruang tambahan atau perluasan ruang, maka lahan bagian belakang lebih dulu dimanfaatkan dari pada bagian lainnya. Jadi selama masih ada lahan privat yang dapat dibangun, masyarakat kampung kota cenderung memaksimalkan pemanfaatan lahan tersebut. Sedangkan pengembangan vertikal dilakukan bila sudah tidak ada lagi lahan privat yang dapat dibangun oleh masyarakat kampung kota (lihat Gambar 6a, 6b, dan 8).
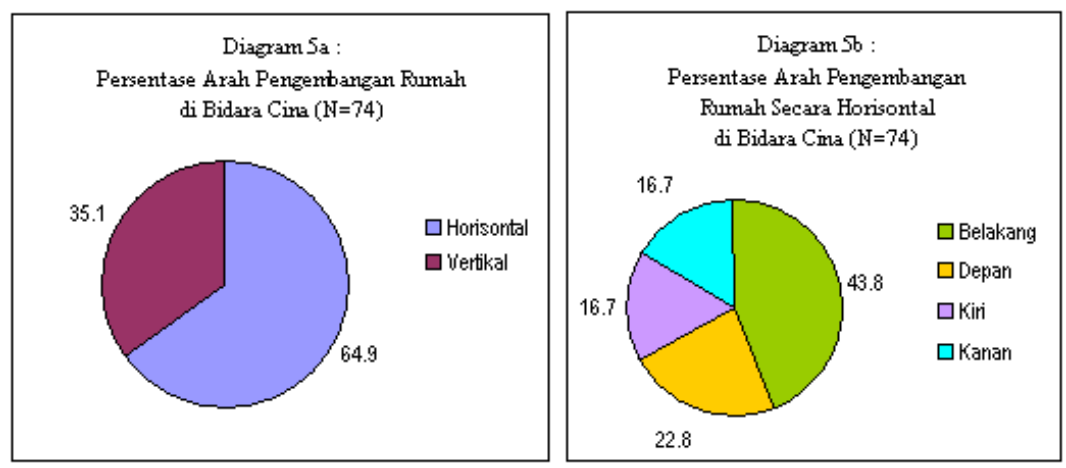

Gambar 6a Presentase Arah Pengembangan Rumah di Bidara Cina;

Gambar 6b Presentase Arah Pengembangan Rumah secara Horizontal di Bidara Cina

Kegiatan pengembangan rumah terkait juga dengan ketersediaan ruang dalam suatu rumah. Saat ini jenis ruang yang ada pada rumah ampong kota umumnya berjumlah tujuh (7) ruang. Dari hasil ampon diketahui bahwa responden yang menyatakan memiliki tujuh jenis ruang $54.5 \%$ responden, sisanya menyatakan memiliki enam jenis ruang, lima jenis ruang, dan delapan jenis ruang. Kondisi ini berlaku di tiga area kepadatan yang berbeda (lihat Gambar 7a dan 7b). Jumlah jenis ruang yang ada dalam rumah ampong kota tergantung dari tingkat kepentingan ruang-ruang tersebut bagi penghuni rumah. Ruang-ruang yang oleh penghuni dianggap sangat penting dalam suatu rumah, menjadi ruang-ruang utama yang cenderung dibangun atau dikembangkan pertama kali. Sedangkan ruang-ruang yang dianggap penting ada dalam suatu rumah, menjadi ruang-ruang penunjang yang dikembangkan kemudian setelah kebutuhan ruang-ruang utama terpenuhi. Jadi ruang-ruang utama yang berjumlah 5 ruang terdiri dari (1) ruang tidur, (2) $\mathrm{KM} / \mathrm{WC}$, (3) ruang tamu, (4) dapur, dan (5) teras menjadi kebutuhan primer. Sedangkan ruang-ruang penunjang yang berjumlah 3 ruang terdiri dari (1) ruang keluarga, (2) ruang makan, dan (3) ruang tempat usaha/warung menjadi kebutuhan sekunder Dengan demikian semakin penting suatu ruang bagi penghuni, maka ruang tersebut akan cenderung diutamakan untuk dibangun dan diperluas dalam suatu rumah.
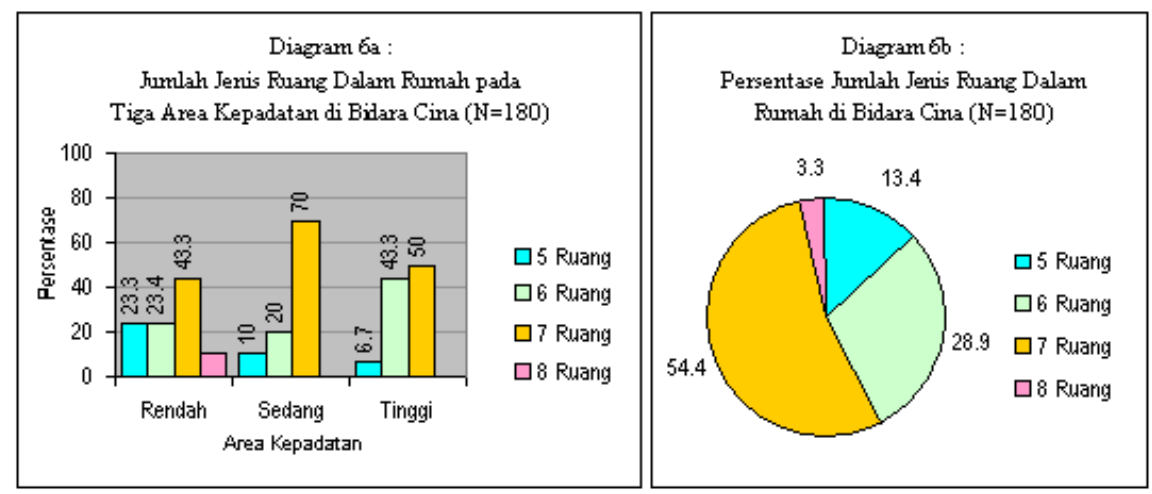

Gambar 7a Jumlah Jenis Ruang dalam Rumah pada Tiga Area Kepadatan di Bidara Cina; Gambar 7b Presentase Jumlah Jenis Ruang dalam Rumah di Bidara Cina 


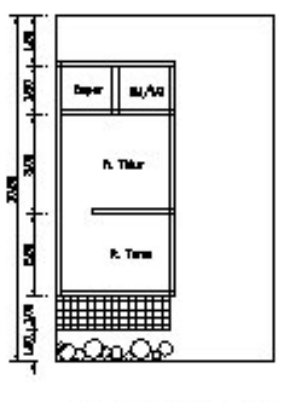

Pembangunan Awal

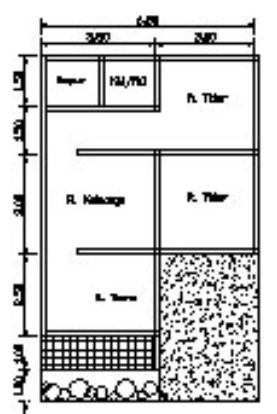

Tahop 1

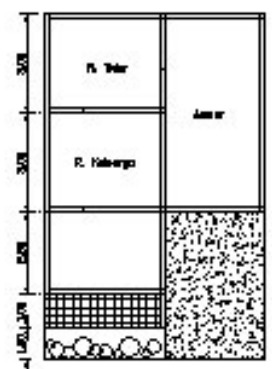

Tahap 2

Gambar

Perspektif Axonometri Proses Pengembangan Rumah

Pembangunan Awal

Tahap 1

Tahap 2

Gambar 8 Tahap Pengembangan Rumah di Kampung Kota
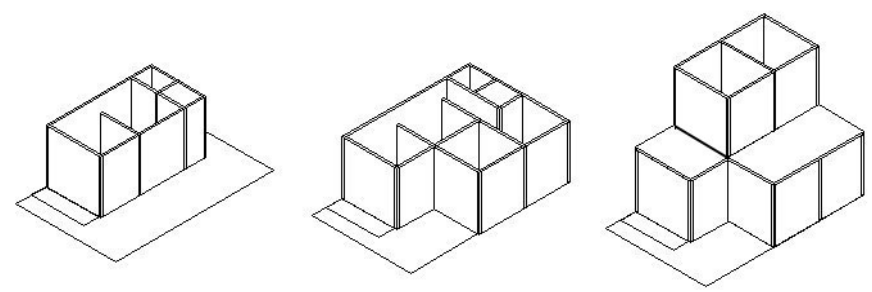

Gambar 9 Tahapan dan proses pengembangan rumah di lingkungan kampung kota

\section{Faktor-Faktor yang Mempengaruhi Pola Pengembangan Rumah}

Kegiatan pengembangan rumah yang dilakukan oleh masyarakat kampung kota dipengaruhi oleh faktor intern yang berasal dari dalam diri individu, dan faktor ekstern yang berasal dari luar diri individu atau dari lingkungannya. Faktor-faktor tersebut mempengaruhi keputusan individu dalam melakukan kegiatan pengembangan rumah pada lahan privat yang mereka miliki. Dari semua faktorfaktor yang telah diuji korelasinya, dengan melihat tingkat signifikansi $\alpha<0.05$ didapat hasil bahwa faktor-faktor yang mempengaruhi pola pengembangan rumah di kampung kota adalah antara lain faktor sosial-budaya, faktor kebutuhan manusia yaitu motivasi pengembangan rumah yang dilakukan masyarakat, faktor ekonomi, faktor kondisi fisik rumah, dan faktor non fisik rumah (status tanah dan rumah). Dengan mengetahui pengaruh faktor-faktor tersebut terhadap pola pengembangan rumah yang dilakukan oleh masyarakat di kampung kota, maka diharapkan pengendalian kegiatan pengembangan rumah di kampung kota dapat dilaksanakan dengan baik dan tidak berdampak negatif pada lingkungan, melalui pendekatan yang sesuai dengan kondisi lingkungan setempat.

Dari faktor sosial-budaya masyarakat kampung kota Bidara Cina, faktor-faktor yang dominan mempengaruhi keputusan individu dalam kegiatan pengembangan rumahnya adalah jumlah KK dalam satu rumah, jumlah anggota keluarga, asal penduduk, lama tinggal di Bidara Cina, dan kegiatan masyarakat yang diikuti oleh individu. Sedangkan faktor suku bangsa, agama, dan aturan membangun yang berlaku di masyarakat merupakan faktor-faktor yang dominan mempengaruhi pola tata ruang di lingkungan kampung Bidara Cina. Faktor usia KK, pendidikan ibu dan bapak merupakan faktor-faktor 
yang cukup mempengaruhi pola pengembangan rumah secara tidak langsung, karena faktor-faktor ini lebih mempengaruhi tingkat kesadaran individu dalam penyediaan lahan resapan air pada lahan privat mereka. Di kampung Bidara Cina, apabila jumlah anggota keluarga bertambah dan kemampuan ekonomi mencukupi maka penghuni cenderung akan melakukan penambahan ruang atau perluasan ruang untuk memenuhi kebutuhan primer atau kebutuhan sekunder dari suatu rumah.

Masyarakat kampung Bidara Cina cenderung tidak memperluas rumah mereka yang asli, terutama masyarakat pribumi. Tetapi dari masyarakat yang mengembangkan rumah, masyarakat pendatang cenderung mengembangkan rumah mereka. Kondisi ini terjadi karena semakin banyak kaum pendatang yang menetap dan melakukan pembangunan atau perluasan rumah di kampung Bidara Cina, sehingga kebutuhan akan rumah meningkat dan perluasan lahan permukiman bertambah atau semakin padat oleh bangunan. Lamanya individu tinggal di kampung Bidara Cina berpengaruh pada kegiatan pengembangan rumah. Semakin lama masyarakat tinggal di Bidara Cina, masyarakat akan semakin akrab dengan penduduk aslinya dan semakin betah menetap di kampung kota ini, apalagi didukung oleh lokasinya yang strategis dekat pusat kota, status tanah dan status rumah yang jelas yang memungkinkan untuk melakukan pembangunan atau perluasan rumah. Semakin lama menetap di Bidara Cina maka masyarakat cenderung akan melakukan kegiatan pengembangan rumah. Kegiatan masyarakat yang diikuti oleh individu juga dapat berpengaruh pada kegiatan pengembangan rumah. Masyarakat yang sering bersosialisasi atau berinteraksi dengan warga lain cenderung lebih terbuka dan lebih mudah menerima informasi baru dan mudah menerima gaya hidup yang lebih maju. Pada masyarakat kampung kota kemajuan tersebut ditunjukkan pada rumahnya yang selain untuk memenuhi kebutuhan primer juga untuk memenuhi kebutuhan sekunder, dari hanya mementingkan fungsi ruang saja sampai dapat mencerminkan status dan jati diri penghuni atau pemilik rumah tersebut.

Faktor-faktor kondisi fisik rumah yang dominan mempengaruhi pola pengembangan rumah adalah luas tanah dan bangunan asli, KDB awal, dan jumlah lantai bangunan awal. Luas tanah dapat berpengaruh pada pola pengembangan rumah. Di kampung Bidara Cina, masyarakat umumnya menyatakan memiliki luas lahan sebesar $<100 \mathrm{~m}^{2}$. Ini menunjukkan luas lahan privat di kampung Bidara Cina umumnya terbatas atau merupakan lahan sempit, namun luasnya bervariasi di tiga area kepadatan. Dengan luas lahan yang terbatas, masyarakat cenderung membangun dengan memaksimalkan penggunaan lahan privat untuk rumah mereka. Kondisi seperti ini dapat berdampak pada pengurangan lahan resapan air di lingkungan kampung kota.

Luas bangunan sebelum diperluas berpengaruh pada pola pengembangan rumah. Apabila masyarakat menganggap ruang-ruang yang ada dalam rumah mereka masih kurang lengkap dan kurang banyak, maka masyarakat cenderung akan membangun ruang tambahan atau memperluas ruang yang ada. Penambahan luas bangunan ini cenderung dilaksanakan dengan memaksimalkan penggunaan lahan privat, yang akhirnya dapat berdampak pada pengurangan lahan resapan air di lingkungan hunian. Jumlah lantai bangunan sebelum diperluas dapat mempengaruhi pola pengembangan rumah, karena apabila jumlah lantai rumah asli masih satu lantai dan tidak ada lagi lahan yang dapat dibangun maka pembangunan cenderung dilakukan ke arah atas (vertikal). Sehingga bangunan menjadi 1.5 lantai atau 2 lantai, tergantung kebutuhan dan kondisi ekonomi penghuni atau pemilik rumah.

Dari faktor ekonomi, faktor-faktor yang dominan mempengaruhi pola pengembangan rumah adalah pekerjaan, penghasilan rata-rata per bulan, pengeluaran rata-rata perbulan dan biaya yang disediakan untuk rumah. Pekerjaan masyarakat kampung Bidara Cina umumnya adalah pegawai negeri $23.93 \%$ dan pegawai swasta $19.13 \%$. Sisanya $56.94 \%$ terdiri dari pedagang, penjual jasa, pensiunan dan lain-lain. Penghasilan dan pengeluaran rata-rata per bulan dari masyarakat kampung Bidara Cina menunjukkan bahwa sebagian dari masyarakat Bidara Cina pekerjaannya bukan pegawai dan penghasilannya terbatas. Dari hasil survey diketahui bahwa $24.4 \%$ responden berpenghasilan < Rp. 599.999 dan 55.6\% responden berpenghasilan Rp 600.000 - Rp 1.199.999. Sisanya sekitar 20\% 
responden berpenghasilan $\geq \mathrm{Rp}$ 1.200.000. Sedangkan pengeluaran rata-rata per bulan dari masyarakat kampung Bidara Cina adalah 26.7\% responden pengeluarannya $<\mathrm{Rp} 599.999$ dan 57.8\% responden pengeluarannya $\mathrm{Rp} 600.000$ - Rp 1.199.999. Sisanya sekitar $15.5 \%$ responden pengeluarannya $\geq \mathrm{Rp}$ 1.200.000. Masyarakat kampung Bidara Cina juga cenderung tidak menyediakan dana untuk rumah secara khusus, karena penghasilan terbatas sedangkan kebutuhan hidup sehari-hari harus lebih diutamakan. Dari hasil survey diketahui bahwa 65,5\% responden tidak menyediakan biaya untuk rumah, $23,3 \%$ responden menyediakan biaya untuk rumah $<10 \%$ dari pengeluaran rumah tangga dan $11,1 \%$ responden menyediakan biaya untuk rumah $10 \%-20 \%$ dari pengeluaran rumah tangga.

Penjelasan-penjelasan di atas menunjukkan bahwa masyarakat kampung kota Bidara Cina umumnya adalah masyarakat dengan golongan ekonomi menengah ke bawah yang kemampuannya terbatas, terutama dalam menyediakan dana untuk pengembangan rumah. Apabila kondisi ekonomi meningkat, maka masyarakat cenderung akan melakukan pengembangan rumah. Jadi kondisi ekonomi dapat mempengaruhi keputusan individu dalam pengembangan rumahnya. Pengembangan rumah yang dilakukan oleh masyarakat kampung kota dengan tingkat ekonomi menengah ke bawah cenderung berdampak bagi penurunan kualitas lingkungan, yaitu pengurangan lahan yang dapat meresapkan air di lingkungan permukiman kampung kota.

Faktor-faktor kondisi non fisik rumah yang paling dominan mempengaruhi pengembangan rumah oleh masyarakat kampung Bidara Cina adalah jenis surat tanah. Sedangkan status tanah dan rumah menjadi faktor yang cukup mempengaruhi pengembangan rumah di Bidara Cina. Jenis surat tanah yang kuat dan jelas kepemilikannya akan menambah keyakinan individu dalam mengembangkan rumahnya, karena di Bidara Cina status tanah umumnya adalah tanah negara.

\section{SIMPULAN}

Masyarakat kampung kota umumnya adalah masyarakat golongan menengah ke bawah. Masyarakat kampung kota melakukan kegiatan membangun dan memperluas rumahnya cenderung untuk memenuhi kebutuhan primer yang terkait dengan rumah, karena keterbatasan kemampuan ekonomi dan luas lahan privat yang terbatas. Pemenuhan kebutuhan sekunder (penunjang) akan rumah dipenuhi oleh masyarakat apabila ada peningkatan kemampuan ekonomi.

Arah pengembangan horisontal yang cenderung dilakukan dalam kegiatan pembangunan dan pengembangan rumah adalah ke arah belakang, kemudian ke arah depan, ke kiri dan ke kanan bangunan. Apabila tidak ada lagi lahan yang dapat dibangun masyarakat mengembangkan rumah secara vertikal. Pengembangan rumah di kampung kota dilakukan secara bertahap, swadaya dan swadana. Ruang-ruang yang cenderung dikembangkan oleh masyarakat kampung kota adalah ruang tidur dan ruang keluarga. Semakin tinggi tingkat ekonomi keluarga, maka rumahnya cenderung memiliki jumlah ruang semakin banyak dan jenis ruang semakin lengkap. Pembangunan dan perluasan atau pengembangan rumah oleh masyarakat kampung kota yang cenderung memaksimalkan penggunaan lahan privat secara horizontal mengakibatkan penurunan luas lahan resapan air di lingkungan kampung kota.

Faktor-faktor yang dominan mempengaruhi pola pengembangan rumah di kampung kota secara berurutan adalah (1) faktor sosial-budaya, (2) faktor kondisi fisik rumah, (3) faktor ekonomi, (4) faktor kebutuhan manusia dan (5) faktor non fisik rumah (status tanah dan rumah). 


\section{DAFTAR PUSTAKA}

Anung. (10 Pebruari, 2002). Jakarta Tenggelam. Kompas, halaman 32.

Sai, S. (1993). Sikap Penghuni Terhadap Kondisi Fisik Bangunan Rumah Asli dan Halaman dalam Hubungannya dengan Kecenderungan Pengembangan Bangunan Rumah dan Pemanfaatan Halama. Tesis tidak diterbitkan. Yogyakarta: Program Pascasarjana Universitas Gadjah Mada.

Tobing, A. D. (5 Oktober, 2002). City Administration and Urban Development Planning of Jakarta. Makalah Seminar Urban Planning and Design. 